\title{
18F-FLT Positron Emission Tomography/Computed Tomography Imaging in Pancreatic Cancer: Determination of Tumor Proliferative Activity and Comparison with Glycolytic Activity as Measured by I8F-FDG Positron Emission Tomography/Computed Tomography
} \section{Imaging}

\author{
Pankreas Kanserinde 18F-FLT Pozitron Emisyon Tomografi/Bilgisayarlı Tomografi \\ Görüntülemesi: Tümör Çoğalma Hızının Belirlenmesi ve I8F-FDG Pozitron Emisyon \\ Tomografi/Bilgisayarıı Tomografi ile Ölçülen Glikolitik Aktivite ile Karşısştırılması
}

\author{
Senait Aknaw Debebe1, Mohammed Goryawala², Malek Adjouadi2, Anthony J. Mcgoron', Seza A. Güleç3 \\ IFlorida International University, College of Engineering and Computing, Department of Biomedical Engineering, Miami, USA \\ 2Florida International University, College of Engineering and Computing, Center for Advanced Technology and Education, Miami, USA \\ ${ }^{3}$ Florida International University, Herbert Wertheim College of Medicine, Department of Surgical Oncology, Miami, USA
}

\begin{abstract}
Objective: This phase-l imaging study examined the imaging characteristic of 3 '-deoxy-3'-(18F)-fluorothymidine (18F-FLT) positron emission tomography (PET) in patients with pancreatic cancer and comparisons were made with (18F)-fluorodeoxyglucose (18F-FDG). The ultimate aim was to develop a molecular imaging tool that could better define the biologic characteristics of pancreas cancer, and to identify the patients who could potentially benefit from surgical resection who were deemed inoperable by conventional means of staging.

Methods: Six patients with newly diagnosed pancreatic cancer underwent a combined FLT and FDG computed tomography (CT) PET/CT imaging protocol. The FLT PET/CT scan was performed within 1 week of FDG PET/CT imaging. Tumor uptake of a tracer was determined and compared using various techniques; statistical thresholding (z score $=2.5)$, and fixed standardized uptake value (SUV) thresholds of 1.4 and 2.5, and applying a threshold of $40 \%$ of maximum SUV (SUV $\max$ ) and mean

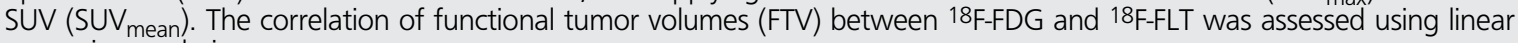
regression analysis.

Results: It was found that there is a correlation in FTV due to metabolic and proliferation activity when using a threshold of SUV 2.5 for FDG and 1.4 for FLT ( $r=0.698, p=n s)$, but a better correlation was obtained when using SUV of 2.5 for both tracers $(r=0.698, p=n s)$. The $z$ score thresholding $(z=2.5)$ method showed lower correlation between the FTVs $(r=0.698, p=n s)$ of FDG and FLT PET.

Conclusion: Different tumor segmentation techniques yielded varying degrees of correlation in FTV between FLT and FDGPET images. FLT imaging may have a different meaning in determining tumor biology and prognosis.

Keywords: 18F-fluorothymidine, 18F-fluorodeoxyglucose, positron emission tomography/computed tomography, pancreatic cancer imaging, image processing, tumor proliferative activity, tumor glycolytic activity
\end{abstract}

Address for Correspondence: Seza A. Güleç MD, Florida International University, Herbert Wertheim College of Medicine, Department of Surgical Oncology, Miami, USA Phone: (001) (786) 6930821 E-mail: sgulec@fiu.edu Received: 20.11.2015 Accepted: 01.01.2016 


\section{Öz}

Amaç: Bu faz I çalışma 3'-deoxy-3'-(18F)-fluorothymidine (18F-FLT) pozitron emisyon tomografisi (PET) görüntülemesinin pankreas kanseri hastalarındaki karakteristiklerini araştırmış ve sonuçlarını (18F)-fluorodeoxyglucose (18F-FDG) görüntülemesi ile karşılaştırmıştır. Bu çalışmadaki nihai amaç, pankreas kanserinin biyolojik özelliklerini tanımlayan ve pankreas kanseri hastaları arasında standart anatomik görüntüleme yöntemleri ile cerrahi tedavi imkanı olmadığı sonucuna varılan hastalarda cerrahi endikasyonlarının ve sınılarının yeniden tanımlanmasını sağlayacak bir moleküler görüntüleme yöntemi geliştirmektir. Yöntem: Yeni teşhis almış ve hiçbir tedavi görmemiş altı hasta bir hafta ara ile FLT ve FDG bilgisayarlı tomografi (BT) PET/ BT çalışmasına alındı. Tümör radyofarmasötik tutulumu tespit edilerek değişik yöntemlerle karsılaştııldı. İstatistiki eşikleme (z skoru=2,5), sabit standart tutulum değeri standardized uptake value (SUV) olarak 1,4 ve 2,5, ve maksimum SUV değerinin \%40'ı düzeyinde eşikleme yöntemleri denendi. FLT ve FDG ile fonksiyonel tümör hacmi hesaplamaları yapıldı ve ilişkileri lineer regresyon analizi ile araştıııldı.

Bulgular: FDG için 2,5 SUV ve FLT için 1,4 SUV değerleri kullanıldığında, FDG ve FLT fonksiyonel tümör hacimleri arasında bir korelasyon bulundu ( $r=0.698, p=n s)$. Her iki radyofarmasötik için 2,5 SUV değeri eşik alındığında ise fonksiyonel tümör hacimleri arasında daha iyi bir korelasyon saptandı $(r=0.698, p=n s)$. Z skoru eşikleme yöntemiyle FLT ve FDG fonksiyonel tümör hacimleri arasında zayıf bir ilişki tespit edildi ( $r=0,698, p=n s)$.

Sonuç: Değişik tümör segmentasyon yöntemleri FLT ve FDG fonksiyonel tümör hacimleri arasında değişik derecelerde korelasyon gösterdi. FLT görüntülemesi tümör biyolojisinin belirlenmesinde farklı bir anlamı ve prognostik değeri bulunabilir.

Anahtar kelimeler: 18F-fluorothymidine, 18F-fluorodeoxyglucose, pozitron emisyon tomografisi/bilgisayarlı tomografi, pankreas kanseri görüntülemesi, görüntü analizi, tümör proliferatif aktivitesi, tümör glikolitik aktivitesi

\section{Introduction}

Pancreatic cancer (ductal adenocarcinoma) accounts for approximately 36,800 deaths per year in United States (1). The majority of patients present in the late stages of the disease with locally advanced or metastatic tumors, among which only 10 to $20 \%$ of patients are candidates for resection and hence have any potential for cure. The signs and symptoms of pancreatic cancer vary from vague, nonspecific abdominal complaints to severe jaundice and the diagnosis can often be difficult, especially in the early stages (2). Despite improvements in diagnostic technology and development of new systemic therapy agents, the prognosis of the disease has not shown much improvement. Surgical resection is the only potential curative treatment available for patients with pancreatic cancer (1).

(18F)-fluorodeoxyglucose (FDG) positron emission tomography (PET)/computed tomography (CT) PET/CT has now become a standard imaging technique for most cancers and the majority of cancers exhibit increased glucose metabolism resulting in high concentration of $18 \mathrm{~F}-\mathrm{FDG}$ in lesions. FDG-PET can change the management of pancreatic cancer by revealing unsuspected metastases to liver, bone and lungs, thereby avoiding the morbidity and mortality of unnecessary surgical interventions (3). Proliferative activities of tumors are known to correlate with prognosis (4). Numerous markers have been described to predict the biological behavior of tumors and outcomes following surgical and medical treatment. $\mathrm{Ki}-67$ is a nuclear antigen present only in the nuclei of proliferating cells and Ki-67 immunohistochemistry has been used to evaluate tumors' proliferative activity $(4,5,6)$. Clinical evaluation and quantification of proliferative activity and tumor invasiveness can be performed using $3^{\prime}$-deoxy$3^{\prime}$-(18F)-fluorothymidine (18F-FLT) PET imaging $(7,8,9,10,11)$. $18 \mathrm{~F}-\mathrm{FLT}$ works as a terminator of the growing DNA chain
(12). Actually little 18F-FLT is accumulated in DNA, it is rather retained intracellularly after phosphorylation by thymidine kinase 1 . This is very much analogous to the imaging of the glucose pathway with 18 F-FDG after trapping by hexokinase. Both compounds therefore reflect accumulation by transport and subsequent activation by the first step in the utilization pathways. However, 18F-FLT does not reflect the whole of DNA synthesis just as 18F-FDG does not reflect the whole of glucose use.

In this study, we examined the imaging characteristics of pancreatic cancer patients to determine the correlation between the metabolic and proliferative activity of pancreatic cancer using FDG and FLT PET images, respectively. The parameters of interest were functional tumor volume (FTV), Total glycolytic index (TGI) and Total proliferative index (TPI). FTV, TGI and TPI were determined from both FDG and FLT PET images. These parameters measure the metabolic and proliferation activity of tumors using FDG and FLT PET/CT images, respectively, which have clinical value in the assessment of tumor biology, prognosis, response to treatment evaluation, and patient selection for therapeutic interventions (4).

\section{Materials and Methods}

\section{Inclusion Criteria}

Patients with pancreatic and periampullary tumors were identified by pathological examination. Those who were potential candidates for the trial were further assessed for eligibility. Inclusion criteria were: clinically diagnosed pancreatic cancer (newly diagnosed as well as those under treatment), age $\geq 18$, ability and willingness to give a written consent, life expectancy $>3$ months and Karnofsky performance status $\geq 70$. Patients with age $<18$, inability or unwillingness to give a written consent, life expectancy $<3$ months, Karnofsky performance status $<70$, pregnant or 
nursing women (urine pregnancy test was performed prior to the investigational radiotracer injection) and individuals allergic to FLT were excluded.

\section{Patient Characteristics}

Six patients fulfilling the inclusion criteria were enrolled in the study of which two were females and four were males (median age of 61.5 and range 56-71 years). The demographics of the patients with the estimated anatomic pancreatic volumes are presented in Table 1. The anatomic pancreatic volumes are estimated by outlining the pancreas on abdominal $\mathrm{CT}$ images by an expert radiologist.

\section{Positron Emission Tomography/Computed Tomography Imaging}

The study was performed under a Food and Drug Administration approved Investigational New Drug and after institutional review board review and approval. The 3'-18F-fluoro-3'-deoxy-L-thymidine used in this trial was obtained from Cardinal Health 414, LLC. Administered activities both for $18 \mathrm{~F}-\mathrm{FLT}$ and $18 \mathrm{~F}-\mathrm{FDG}$ were $10 \pm 1 \mathrm{mCi}$ with post injection imaging point of $60 \pm 15$ minutes. Images were obtained with 16-slice Siemens PET/CT camera. The scanning parameters for the CT imaging were $140 \mathrm{kVp}$, $80 \mathrm{~mA}, 0.5 \mathrm{~s}$ rotation time and $512 \times 512$-pixel matrix. CT image sizes range from $512 \times 512 \times 186$ to $512 \times 512 \times 273$. PET image sizes range from $168 \times 168 \times 186$ to $168 \times 168 \times 273$ with voxel size of $4.0627 \times 4.0627 \times 4 \mathrm{~mm}^{3}$.

\section{Methods for Finding Functional Tumor Volumes}

As a first step, FLT PET images were manually coregistered with FDG PET/CT images using AMIDE software, a free tool for viewing, analyzing and registering volumetric medical imaging data sets. Next, an experienced board certified radiologist used the region of interest (ROI) method to isolate the pancreas from $\mathrm{CT}$ images of the FDG PET/CT. After this point, MATLAB ${ }^{\circledR}$ (The MathWorks Inc.) was used to perform automatic tumor segmentation. The Binary masks from the ROls of CT images were mapped to the co-registered FDG PET and FLT PET images to segment the pancreas. Third party interactive application software called ScanIPTM was used in 3D medical image analysis to

Table 1. Patient characteristics

\begin{tabular}{llllll}
\hline $\begin{array}{l}\text { Patient } \\
\text { no }\end{array}$ & $\begin{array}{l}\text { Age } \\
\text { (years) }\end{array}$ & Gender & $\begin{array}{l}\text { Volume of } \\
\text { Pancreas (ml) }\end{array}$ & \multicolumn{2}{c}{ SUV $_{\text {max }}$} \\
\hline 1 & 71 & $\mathrm{M}$ & 206 & 33.21 & 16.52 \\
2 & 67 & $\mathrm{~F}$ & 143 & 5.85 & 2.60 \\
3 & 57 & $\mathrm{M}$ & 248 & 5.45 & 12.25 \\
4 & 56 & $\mathrm{M}$ & 120 & 5.30 & 9.17 \\
5 & 62 & $\mathrm{M}$ & 107 & 1.32 & 3.12 \\
6 & 61 & $\mathrm{~F}$ & 96.3 & 3.46 & 5.12 \\
\hline
\end{tabular}

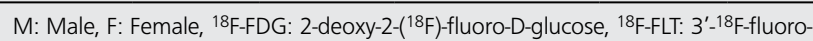
3'-deoxy-L-thymidine, FDG: Fluorodeoxyglucose, FLT: Fluorothymidine estimate the volume of the segmented pancreas. Once the pancreas was segmented from the two images, different thresholding techniques were applied to find the FTVs. We have used statistical and SUV threshold techniques.

Our aim in this study was not to validate different tumor delineation methods, but rather to determine the FTV, TGI and TPI relationships due to the uptake of $18 \mathrm{~F}-\mathrm{FDG}$ and 18F-FLT by using well practiced fixed threshold methods.

\section{Statistical Tumor Segmentation}

The segmented pancreas was normalized by $z$ score transformation using equation 1 , where ' $x$ ' is the pixel intensity value, and ' $\mu$ ' and ' $\sigma$ ' are the mean and standard deviation of the segmented pancreas images, respectively. The $\mathrm{z}$ score transformation procedure for normalizing data is a familiar statistical method in neuroimaging and psychological studies (3). This method converts the original pixel intensity image to a probability map that represents deviations from the normal using voxel-by-voxel comparison, which facilitates image interpretation.

$$
\mathrm{Z}=\frac{\chi-\mu}{\sigma}
$$

The $\mathrm{z}$ score, which transforms the image into a statistical parametric map, was calculated for each pixel. Threshold of $z \geq 2.5$ was then applied which only highlights those pixels which can confidently be labelled as active, i.e. those areas which deviate significantly from the normal (13). Using this technique considers the low tumor to background ratio by comparing each pixel to the surrounding pixels through deviation from the mean.

\section{Standardized Uptake Value (SUV) Based Tumor Segmentation}

SUV provides biological and functional activity of a tumor (14). Quantification of FLT with SUV provides information about cells undergoing active proliferation while SUV of FDG provides information on increased glucose metabolism. SUVs were calculated with mathematical expression shown in equation 2.

$$
\operatorname{SUV}\left(\frac{\mathrm{g}}{\mathrm{ml}}\right)=\frac{\text { Activity Concentration }}{\frac{\text { Injected activity (mCi) }}{\text { Lean body mass (g) }}}
$$

Different SUV thresholds were used to investigate tumor localization; SUV of $1.4,2.5,40 \% S_{\text {SUV }}$ and $S U V_{\text {mean }}$. $S U V_{\text {max }}$ and $S U V_{\text {mean }}$ refer to the maximum and mean SUV values from each individual patient's PET images. One of the methods was using $40 \%$ of the maximum SUV uptake for each patient to segment tumor. Each patient has different maximum SUV uptakes for the radiotracer type, thus the amount of threshold varies accordingly. From the maximum SUVs, $40 \%$ of this value $\left(40 \% S_{\text {SUV }}\right.$ max $)$ 
was applied as a threshold to segment tumors. The same concept was used when the mean SUV (SUV mean) uptake for tumor segmentation was applied. Table 1 shows the maximum SUVs for each patient.

\section{Functional Tumor Volume Measurement}

The voxels, which exceed the applied threshold value, were counted to find the FTV using equation 3 where AV is the active voxel that remained after applying the threshold. Volume of a voxel was $4.0627 \times 4.0627 \times 4 \mathrm{~mm}^{3}$. The FTVs for $18 \mathrm{~F}-\mathrm{FLT}$ and $18 \mathrm{~F}-\mathrm{FDG}$ were then assessed using linear regression analysis.

\section{$A V^{*}$ Volume of a voxel}

\section{Total Glycolytic and Total Proliferative Index Measurements}

The TGI/TPI is the product of functional volume and tumor SUV $V_{\max }$. The FTV were multiplied with the respective $S U V_{\max }$ of the patient.

$$
\mathrm{PI}=\mathrm{FTV} x S U \mathrm{~V}_{\max }
$$

\section{Results}

Results of FTVs $(\mathrm{ml})$ using the different tumor segmentation methods on 18F-FDG and 18F-FLT PET images are presented in Table 2 (A) and (B) respectively. Linear regressions were performed between estimated FTV from 18F-FDG and 18F-FLT PET for the five different thresholding techniques shown in Figure 1. Correlation coefficients $(r), t$ and $p$ values of the linear regression were reported. Analyses were performed two-sided at a $5 \%$ level of significance. Figure 2 shows the $3 \mathrm{D}$ rendered images of the pancreas and segmented tumors using the five different threshold techniques for patient 3 .

FDG and FLT PET images with average maximum SUV uptake of 9.1 (median 5.38, range 1.32-33.21) and 8.1 (median 7.15, range 2.6-16.52), respectively, were analyzed. Results showed a correlation in FTV due to metabolic and proliferation activity. Using a threshold of SUV 2.5 for FDG and 1.4 for FLT, a correlation coefficient ( $r$ ) of 0.9606 (t value $=7.16, p$ value $<0.05$ ) was found. A slightly better correlation was found with SUV of 2.5 for both tracers with of $r=0.973$ ( $t$ value $=8.46$, $p$ value $<0.05$ ). The $p$ values (5\% significance level) from the two SUV methods strongly support that there is a correlation in FTV from ${ }^{18}$ F-FDG and 18 F-FLT PET scans.

Table 2A. Estimated pancreas tumor volumes using (A) 18F-FDG PET/CT Imaging

\begin{tabular}{llllll}
\hline Patient no & $\begin{array}{l}\mathbf{Z} \text { score } \\
(\mathbf{z}=\mathbf{2 . 5})\end{array}$ & $\begin{array}{l}\text { SUV based } \\
\mathbf{( F D G = 2 . 5 , ~ F L T = 1 . 4 )}\end{array}$ & $\begin{array}{l}\text { SUV based } \\
\mathbf{( F D G = 2 . 5 , ~ F L T ~ 2 . 5 )}\end{array}$ & $\mathbf{4 0 \%}_{\text {SUV }}$ & SUV $_{\text {mean }}$ \\
\hline 1 & 30.90 & 126.83 & 126.83 & 8.06 & 59.82 \\
2 & 29.91 & 11.36 & 11.36 & 13.60 & 57.57 \\
3 & 76.39 & 104.65 & 104.65 & 142.28 & 117.12 \\
4 & 11.16 & 5.74 & 5.74 & 10.70 & 52.49 \\
5 & 20.34 & 0.00 & 0.00 & 33.01 & 30.12 \\
6 & 20.86 & 2.25 & 2.25 & 32.42 & 42.58 \\
Average & $31.59 \pm 21.09$ & $41.81 \pm 52.79$ & $41.81 \pm 52.79$ & $40.01 \pm 46.80$ & $59.95 \pm 27.45$ \\
\hline 18F-FDG: 2-deoxy-2-(18F)-fluoro-D-glucose, PET/CT: Positron emission tomography/computed tomography, SUV: Standardized uptake value, &
\end{tabular}

Table 2B. Estimated pancreas tumor volumes using (B) ${ }^{18} \mathrm{~F}-\mathrm{FLT}$ PET/CT Imaging

\begin{tabular}{llllll}
\hline Patient no & $\begin{array}{l}\mathbf{z} \text { score } \\
(\mathbf{z}=\mathbf{2 . 5})\end{array}$ & $\begin{array}{l}\text { SUV based } \\
(\text { FDG=2.5, FLT=1.4) }\end{array}$ & $\begin{array}{l}\text { SUV based } \\
(\text { FDG=2.5, FLT 2.5) }\end{array}$ & $\mathbf{4 0 \%}_{\text {SUV }}$ max & SUV $_{\text {mean }}$ \\
\hline 1 & 20.53 & 146.04 & 67.21 & 9.44 & 63.78 \\
2 & 27.60 & 18.68 & 0.20 & 33.74 & 60.87 \\
3 & 25.42 & 95.14 & 62.00 & 31.69 & 57.90 \\
4 & 8.06 & 38.43 & 15.25 & 9.71 & 17.69 \\
5 & 12.54 & 15.12 & 2.05 & 20.40 & 25.35 \\
6 & 12.74 & 34.60 & 12.94 & 19.41 & 33.94 \\
Average & $17.82 \pm 7.18$ & $58.00 \pm 47.34$ & $26.61 \pm 27.44$ & $20.73 \pm 9.49$ & $43.26 \pm 18.29$ \\
\hline
\end{tabular}

18F-FLT: 3'-18F-fluoro-3'-deoxy-L-thymidine, PET/CT: Positron emission tomography/computed tomography, SUV: Standardized uptake value, FDG: Fluorodeoxyglucose, FLT: Fluorothymidine, Averages values are expressed as mean \pm SD 
Strong correlation between TPI and TGI was found using $40 \%$ of $S U V_{\text {max }}, r$ of 0.9977 (t value $=29.37, p<0.05$ ). The $2^{\text {nd }}$ best correlation between TPI and TGI was observed when threshold of SUV 1.4 for FLT and 2.5 for FDG used with $r=0.9427$ ( $t$ value $=5.65$, $p$ value $<0.05$ ).

The $z$ score threshold $(z=2.5)$ method showed a moderate correlation between FTVs $(r=0.698$, $t$ value $=1.95, p$ value $=n s)$, and TGI and TPI $(r=0.89$, $\mathrm{t}$ value $=3.9$, $\mathrm{p}$ value $<0.05$ ) between the two images. The $p$ values support the null hypothesis that there is no correlation between the FTVs of FDG and FLT PET images with z score method.

\section{Discussion}

There is no universally validated technique for tumor delineation, and manual segmentation is biased by the experience of the nuclear physician and the contouring protocol used. Thureau et al. (15) has suggested using a fixed threshold of SUV 1.4 for 18F-FLT uptake due to the low tumor-to-background ratio in PET images of lung cancer. In addition, it was also demonstrated that using SUV of 1.4 gives a similar result as the method used by physicians to delineate tumors. It is also explained in the literature that the difference in tumor volumes using different SUV thresholds to segment 18 F-FDG uptake was insignificant. Han et al. (16) also concluded that SUV cutoff of 1.4 for 18F-FLT PET/CT and SUV of 2.5 for 18 F-FDG PET/CT provided the best estimate of gross tumor volume. Hellwig et al. (17) demonstrated that SUV of 2.5 thresholds for 18 F-FDG gives a high overall accuracy for clinical images. In our study, SUV cutoff values that showed to be reproducible were used for tumor segmentation. The resulting volumes
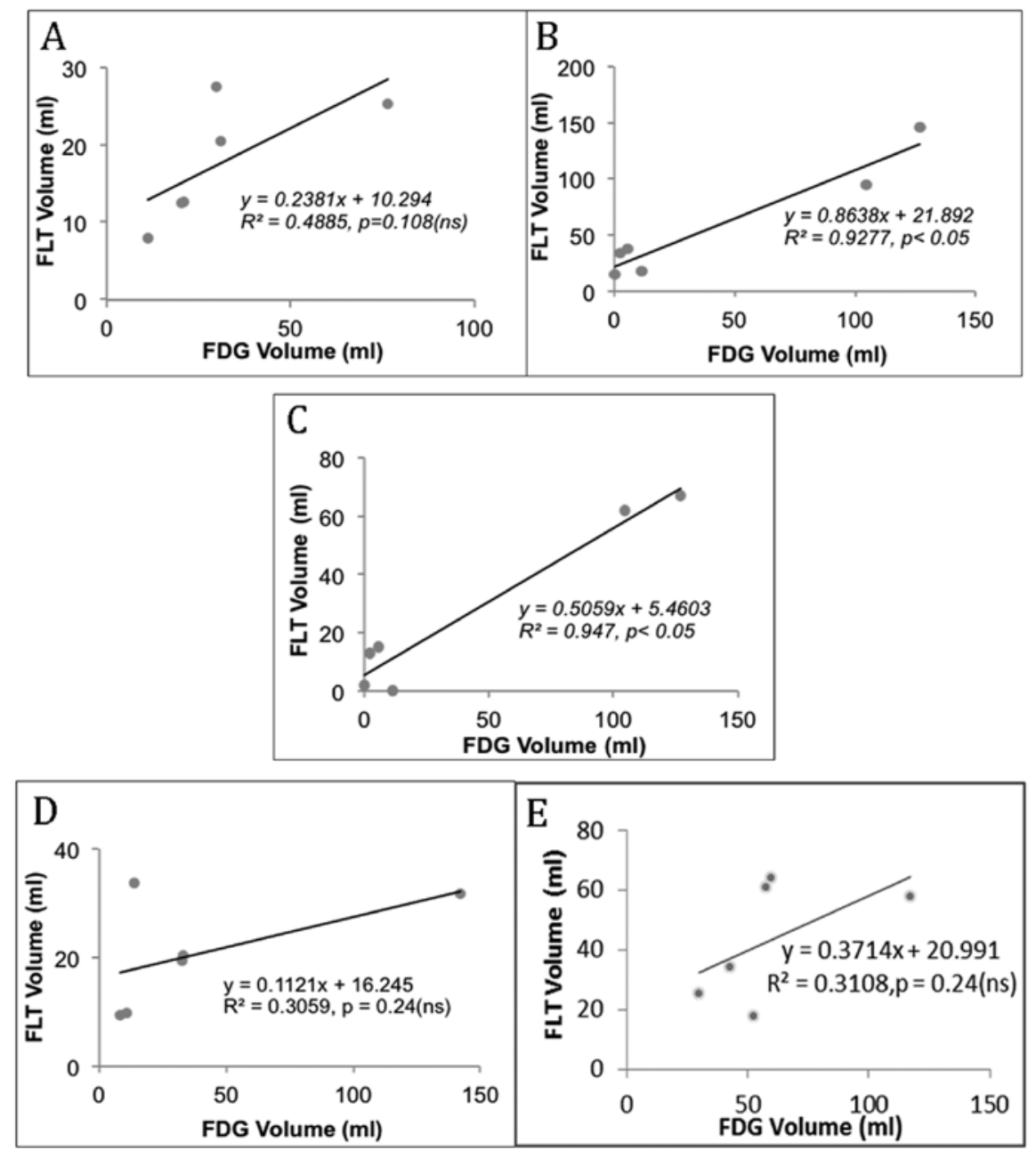

Figure 1. Functional tumor volume relationships using (A) z score thresholding, (B) SUV cutoffs of 2.5 for FDG and 1.4 for FLT (C) SUV cutoffs of 2.5 for both FDG\&FLT (D) $40 \%$ of SUV max $_{\text {thesholding (E) SUV mean }}$ threshold FDG:Fluorodeoxyglucose, FLT: Fluorothymidine 
from 18F-FDG and 18F-FLT PET images were compared for correlation.

In our study, the FLT PET images demonstrated physiologic uptake in the liver and bone marrow. The activity in the normal pancreatic tissue was at the background level. FLT uptake in the tumors was at variable intensity and did not encompass the entirety of the FDG-positive regions in the tumor's topography. Determining FTV from FLT PET images is challenged by partial volume effect (in small tumors), and is subject to errors from manual tumor segmentation that might result in underestimation. These drawbacks have been explained as a reason for negative results in FLT PET scans (18). The FTV from FDG PET images could also be potentially challenged by the enhancement of FDG activity from a peritumoral inflammatory response. Thus, a technique that is ideal for FDG images might not necessarily be applicable to FLT images. To address these technical difficulties, we used semiautomatic segmentation

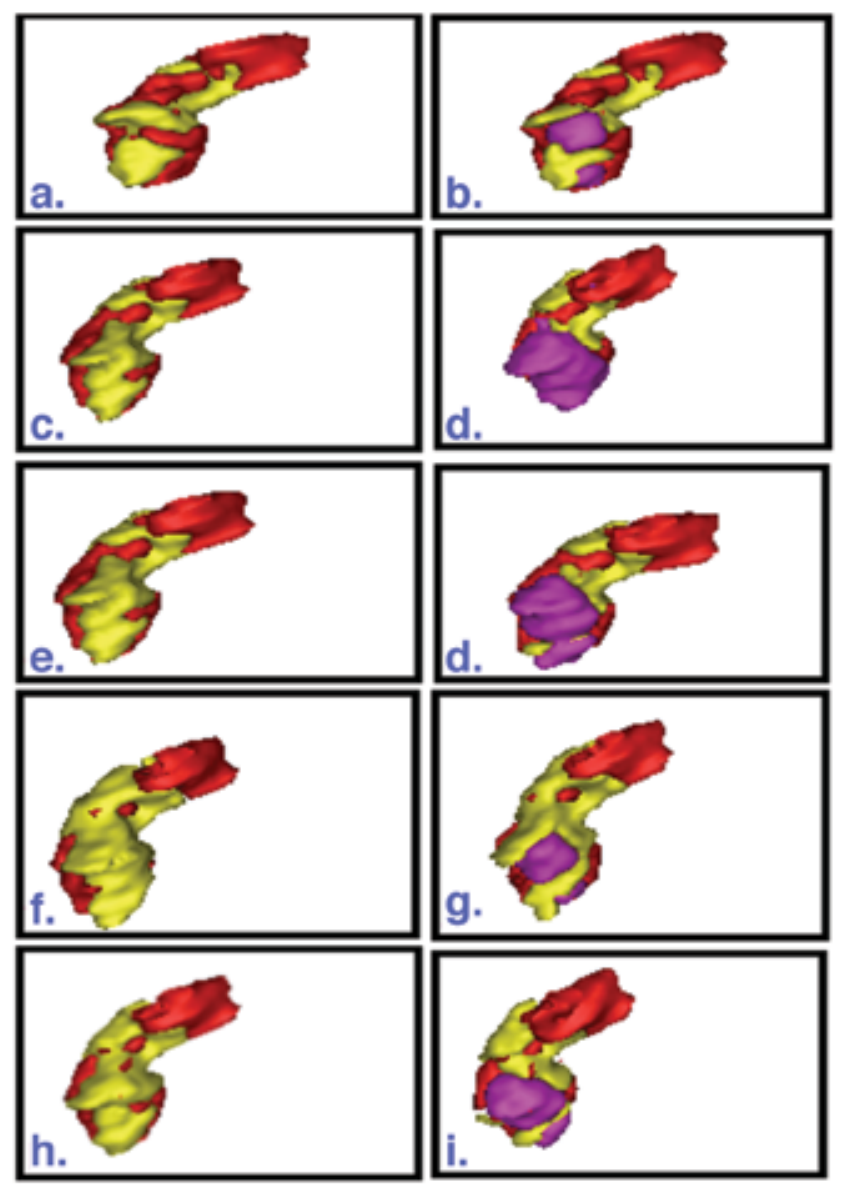

Figure 2. $3 D$ rendered volume of pancreas (red) and tumor volume delineated based on the uptake of only FDG (yellow) (left), and FDG and FLT (pink) superimposed (right) for patient 3 using (a)-(b) z score, (c)-(d) SUV of 2.5 (FDG) \& 1.4 (FLT), (e)-(f) SUV of 2.5 for both tracers, (f)-(g) $40 \%$ SUV $V_{\text {max }}$ and (h)-(i) SUV $V_{\text {mean }}$ thresholding methods. The primary aim of this study was to assess and compare the topography and size of FTV from proliferation (FLT PET) and metabolic (FDG PET) images.

In this study, the pancreas was first segmented from 18F-FDG CT scans by an experienced radiologist. The segmented pancreas was then mapped to co-registered 18F-FDG and 18F-FLT PET images. Different thresholding techniques were applied to automatically segment tumors from the PET scans.

We used two major methods; statistical and SUV methods. To our knowledge, this study is the first to use a statistical (z score) and fixed SUV thresholds on FLT and FDG PET/CT images of pancreatic cancer in tumor segmentation. The use of $z$ score threshold considers all pixels inside the pancreas and delineates only those pixels that deviate considerably from the mean activity inside the pancreas. In the case of FLT PET images that have very low contrast, this method provides an excellent way to differentiate between background and tumor pixel intensities. Z scores on FLT images take into consideration the overall organ uptake since not every organ has similar cell proliferation rates. This method might not provide an alternate choice for FDG PET images where tumor to background uptake is well segregated.

The SUV cutoffs $\left(2.5,1.4,40 \%\right.$ SUV $_{\text {max }}$ and SUV mean $)$ presented here to segment tumor volumes have been tested to be reproducible in tumor volume delineation $(15,17,19)$. We have found different FTVs from FDG and FLT PET images, which might result in different treatment planning and different dose delivery if either of the two tracers is used for diagnostics workup. This might imply that giving a treatment solely based on FLT or FDG uptake might be misleading suggesting that incorporating the two images can be beneficial in treatment planning.

There is a satisfactory FTV correspondence between FDG and FLT PET when SUV cutoffs of 2.5 and 1.4, respectively, are used for tumor segmentation. The correlation between TGI and TPI is seen to be high when a threshold of $40 \%$ of SUV max is used but this method also gave the highest probability of false prediction.

Though the volumes delineated as a tumor from the two images do not always occur in the same place of the pancreas, our study showed that FTVs from 18F-FDG and 18F-FLT PET images do have correlation. In most patients, it was observed that tumors segmented from FLT PET images occur at the head of the pancreas (Figure 2). Thureau et al. (15) postulated that proliferative volume should not be greater than metabolic volume. In our study, the $\mathrm{z}$ score method yielded higher tumor volumes from 18F-FDG than 18F-FLT PET images in all patients unlike the SUV methods where this result was variable from patient to patient.

In conclusion, the FTVs correlation seen between FDG and FLT PET scans depends on the type of tumor segmentation technique used. SUV based thresholds showed correlations in the FTVs but z score method showed no correlations of FTVs between FDG and FLT PET scans. 


\section{Conclusions}

Different tumor segmentation techniques yielded varying degree of correlation in functional tumor values between FLT and FDG PET images. The statistical threshold technique showed higher tumor volumes from FDG images than from FLT PET images in all patients. Due to the limited number of patients and the lack of a gold standard, further investigation is required to fully appreciate correlations in tumor topography and size between 18F-FDG PET and 18F-FLT PET images.

\section{Authorship Contributions}

Ethics Committee Approval: This study was approved by Western Institutional Review Board, Informed Consent: Consent form was filled out by all participants. Concept: Seza A. Güleç, Design: Seza A. Güleç, Data Collection or Processing: Seza A. Güleç, Senait Aknaw Debebe, Mohammed Goryawala, Analysis or Interpretation: Seza A. Güleç, Senait Aknaw Debebe, Mohammed Goryawala, Malek Adjouadi, Anthony J. Mcgoron, Literature Search: Seza A. Güleç, Senait Aknaw Debebe, Writing: Senait Aknaw Debebe, Mohammed Goryawala, Malek Adjouadi, Anthony J. Mcgoron, Seza A. Güleç, Peer-review: Externally peer-reviewed, Conflict of Interest: No conflict of interest was declared by the authors, Financial Disclosure: The study was supported by Arthur Rupe Foundation Grant for pancreatic cancer research

\section{References}

1. American Cancer Society. Cancer Facts \& Figures 2013. Atlanta: American Cancer Society; 2013., pp. 1-64.

2. American Cancer Society. Pancreatic Cancer. Hamilton London: BC Decker Inc; 2001. pp. 153

3. Cheadle C, Vawter MP, Freed WJ, Becker KG. Analysis of microarray data using Z score transformation. J Mol Diagn 2003:5:73-81.

4. Gulec SA, Suthar RR, Barot TC, Pennington K. The prognostic value of functional tumor volume and total lesion glycolysis in patients with colorectal cancer liver metastases undergoing 90Y selective internal radiation therapy plus chemotherapy. Eur J Nucl Med Mol Imaging 2011;38:1289-1295.

5. Bhatt R, Adjouadi M, Goryawala M, Gulec SA, McGoron AJ. An algorithm for PET tumor volume and activity quantification: without specifying camera's point spread function (PSF). Med Phys 2012;39:4187-4202.

6. Goryawala M, Guillen MR, Cabrerizo M, Barreto A, Gulec S, Barot TC, Suthar RR, Bhatt RN, Mcgoron A, Adjouadi M. A 3-D liver segmentation method with parallel computing for selective internal radiation therapy. IEEE Trans Inf Technol Biomed 2012;16:62-69.

7. Chen W, Cloughesy T, Kamdar N, Satyamurthy N, Bergsneider M, Liau L, Mischel P, Czernin J, Phelps ME, Silverman DH. Imaging proliferation in brain tumors with 18F-FLT PET: comparison with 18F-FDG. J Nucl Med 2005:46:945-952.
8. Cobben DC, Jager PL, Elsinga PH, Maas B, Suurmeijer AJ, Hoekstra HJ. 3'-18F-fluoro-3'-deoxy-L-thymidine: a new tracer for staging metastatic melanoma?. J Nucl Med 2003:44:1927-1932.

9. Buck AK, Halter $G$, Schirrmeister $H$, Kotzerke J, Wurziger I, Glatting G, Mattfeldt T, Neumaier B, Reske SN, Hetzel M. Imaging proliferation in lung tumors with PET: 18F-FLT versus 18F-FDG. J Nucl Med 2003;44:1426-1431.

10. Cobben $D C$, Elsinga $P H$, Hoekstra $H J$, Suurmeijer $A J$, Vaalburg $W_{t}$ Maas B, Jager PL, Groen HM. Is 18F-3'-fluoro-3'-deoxy-L-thymidine useful for the staging and restaging of non-small cell lung cancer? J Nucl Med 2004;45:1677-1682.

11. Quon A, Chang ST, Chin F, Kamaya A, Dick DW, Loo BW Jr, Gambhir SS, Koong AC. Initial evaluation of 18F-fluorothymidine (FLT) PET/CT scanning for primary pancreatic cancer. Eur J Nucl Med Mol Imaging 2008;35:527-531.

12. Turcotte $E$, Wiens LW, Grierson JR, Peterson LM, Wener MH, Vesselle $\mathrm{H}$. Toxicology evaluation of radiotracer doses of $3^{\prime}$-deoxy-3'-(18F) fluorothymidine (18F-FLT) for human PET imaging: Laboratory analysis of serial blood samples and comparison to previously investigated therapeutic FLT doses. BMC Nucl Med 2007;7:3.

13. Ishii K, Sasaki M, Matsui M, Sakamoto S, Yamaji S, Hayashi N, Mori E. A diagnostic method for suspected Alzheimer's disease using $\mathrm{H} 2150$ positron emission tomography perfusion Z score. Neuroradiology 2000;42:787-794.

14. Mesoloras G, Sandison GA, Gulec SA. Measurement of Functional Tumor Volume for Fluorodeoxyglucose-Positive Primary and Metastatic Liver Tumors: Validation of Optimal Threshold Value Technique. J Interv Oncol 2009;2.

15. Thureau S, Chaumet-Riffaud $P$, Modzelewski $R$, Fernandez $P$, Tessonnier L, Vervueren L, Cachin F, Berriolo-Riedinger A, Olivier P, Kolesnikov-Gauthier H, Blagosklonov O, Bridji B, Devillers A, Collombier L, Courbon F, Gremillet E, Houzard C, Caignon JM, Roux J, Aide N, Brenot-Rossi I, Doyeux K, Dubray B, Vera P. Interobserver agreement of qualitative analysis and tumor delineation of 18F-fluoromisonidazole and 3'-deoxy-3'-18F-fluorothymidine PET images in lung cancer. J Nucl Med 2013;54:1543-1550.

16. Han $D, Y u$ J, Yu Y, Zhang G, Zhong $X$, Lu J, Yin Y, Fu Z, Mu D, Zhang B, He W, Huo Z, Liu X, Kong L, Zhao S, Sun X. Comparison of 18 F-fluorothymidine and 18 F-fluorodeoxyglucose PET/CT in delineating gross tumor volume by optimal threshold in patients with squamous cell carcinoma of thoracic esophagus. Int J Radiat Oncol Biol Phys 2010;76:1235-1241.

17. Hellwig D, Graeter TP, Ukena D, Groeschel A, Sybrecht GW, Schaefers HJ, Kirsch CM 18F-FDG PET for mediastinal staging of lung cancer: which SUV threshold makes sense?. J Nucl Med 2007;48:1761-1766.

18. Herrmann $K$, Erkan $M$, Dobritz $M$, Schuster $T$, Siveke JT, Beer $A J$, Wester HJ, Schmid RM, Friess H, Schwaiger M, Kleeff J, Buck AK. Comparison of $3^{\prime}$-deoxy-3'-(18F) fluorothymidine positron emission tomography (FLT PET) and FDG PET/CT for the detection and characterization of pancreatic tumours. Eur J Nucl Med Mol Imaging 2012:39:846-851.

19. Kenny LM, Vigushin DM, Al-Nahhas A, Osman S, Luthra SK, Shousha S, Coombes RC, Aboagye EO. Quantification of cellular proliferation in tumor and normal tissues of patients with breast cancer by (18F) fluorothymidine-positron emission tomography imaging: evaluation of analytical methods. Cancer Res 2005;65:10104-10112. 